\title{
MENINGKATKAN HASIL BELAJAR SISWA PADA MATERI SIFAT-SIFAT BANGUN DATAR DENGAN MENGGUNAKAN ALAT PERAGA DUA DIMENSI DI KELAS IV SDN 1 KATOI
}

\author{
Kamaruddin $^{1)}$, La Ode Kaimuddin ${ }^{2}$ \\ 1) SDN 1 Katoi, Kolaka Utara, Indonesia \\ ${ }^{2)}$ Jurusan PGSD, Universitas Halu Oleo, Kendari, Indonesia \\ email: kamaruddin.pji@gmail.com
}

\begin{abstract}
Abstrak: Tujuan penelitian ini adalah untuk meningkatkan hasil belajar matematika siswa dalam memahami sifat-sifat bangun datar di kelas IV SD Negeri 1 Katoi Kabupaten Kolaka Utara. Penelitian ini adalah Penelitian Tindakan Kelas (PTK) meliputi perencanaan, pelaksanaan tindakan, observasi dan refleksi. Data yang didapatkan dari hasil tes dan observasi dianalisis menggunakan tehnik analisis statistik deskriptif. Sebagai indikator kinerja keberhasilan penelitian tindak kelas ini adalah minimal $80 \%$ rencana perbaikan pembelajaran telah terlaksana dan hasil belajar siswa secara klasikal minimal $80 \%$ telah memperoleh skor nilai KKM sebesar 60. Hasil analisis data dikemukakan bahwa untuk prosentase keaktifan belajar siswa dari pertemuan I sebesar 53,8\%, dan pertemua II sebesar 76,9\%. Hasil analisis data pengamatan pada aktifitas mengajar guru: Pertemuan I sebesar $69,2 \%$, dan pertemuan II 92,3\%. Selanjutnya untuk analisis data pada siklus II, dikemukakan bahwa prosentase aktifitas belajar siswa sebesar $84,6 \%$ pada pertemuan I dan $100 \%$ pada pertemuan II. Persentase keaktifan mengajar guru pertemuan I sebesar 93,3\% dan pada pertemuan II 100\%. Berdasarkan hasil penelitian tersebut dapat disimpulkan bahwa penggunaan alat peraga dua dimensi dapat meningkatkan aktivitas mengajar guru, aktivitas belajar siswa pada Materi Sifat-sifat Bangun Datar kelas IV SD Negeri 1 Katoi Kabupaten Kolaka Utara.
\end{abstract}

Kata Kunci: alat peraga dua dimensi; hasil belajar siswa

\section{IMPROVING THE STUDENT'S LEARNING OUTCOMES ON THE PROPERTIES OF FLAT WAKING UP USING TWO DIMENSION TOOLS IN KELAS IV SDN 1 KATOI}

\begin{abstract}
The aim of the study was to improve students' mathematics learning outcomes in understanding the properties of flat shapes in grade IV SD Negeri 1 Katoi, North Kolaka Regency. This research is a Classroom Action Research (PTK) which includes planning, implementing actions, observing and reflecting. The data obtained from the test results and observations were analyzed using descriptive statistical analysis techniques. As an indicator of the performance of the success of this classroom action research is that at least $80 \%$ of the learning improvement plan has been implemented and classical student learning outcomes of at least $80 \%$ have obtained a KKM score of 60. The results of the data analysis stated that the percentage of student learning activeness from the first meeting was $53.8 \%$, and the second meeting was 76.9\%. The results of the analysis of observational data on teacher teaching activities: Meeting I was $69.2 \%$, and meeting II was $92.3 \%$. Furthermore, for data analysis in cycle II, it was stated that the percentage of student learning activities was $84.6 \%$ at the first meeting and $100 \%$ at the second meeting. The percentage of teaching activeness in the first meeting was $93.3 \%$ and at the second meeting it was 100\%. Based on the results of this study, it can be concluded that the use of two-dimensional teaching aids can improve teacher teaching activities, student learning activities on the Material Characteristics of Flat Building for Grade IV SD Negeri 1 Katoi, North Kolaka Regency.
\end{abstract}

Keywords: two-dimensional props; student learning outcomes; 


\section{Pendahuluan}

Perkembangan ilmu pengetahuan dan teknologi yang sangatpesatmenuntut upaya peningkatan kualitas sumber daya manusia yang mempunyai posisi strategis bagi keberhasilan pembangunan nasional secara berkelanjutan. Oleh karena itu, upaya tersebut mutlak harus mendapat perhatian yang sungguh-sungguh dan harus dirancang secara sistematis dan seksama berdasarkan pemikiran yang matang. Wadah yang tepat bagi upaya peningkatan kualitas sumber pendidikan antara lain melalui peningkatan kinerja guru dan peningkatan mutu pelajaran yang melibatkan MBS, Pakem serta peran serta masyarakat.

Dalam kaitannya dengan PAKEM, guru dituntut untuk menciptakan suasana pembelajaran yang kondusif, yaitu pembelajaran yang aktif, kreatif, efektif, dan menyenangkan. Situasi pakem tersebut harus diupayakan untuk semua mata pelajaran. Dengan begitu, diharapkan peningkatan mutu pendidikan dapat tercapai secara optimal.

Matematika merupakan disiplin ilmu yang bersifat khas. Salah satu kekhasannya adalah bersifat abstrak.Sifat inilah yang sering menimbulkan masalah bagi seseorang dalam mempelajari matematika, padahal matematika mempunyai peran penting dalam kehidupan manusia. Berkaitan dengan hal tersebut, Hudoyo (2000, p.2) menyatakan bahwa matematika merupakan pengetahuan yang esensial sebagai dasar untuk bekerja seumur hidup dalam era globalisasi.

Namun demikian, kenyataan menunjukkan bahwa perolehan nilai pelajaran matematika peserta didik dari semua jenjang pendidikan dari sekolah dasar sampai perguruan tinggi diakui masih rendah. Hal ini dapat dibuktikan dengan pengamatan saya sebagai guru di kelas V di SD Negeri 1 Katoi Kabupaten Kolaka Utara yang menunjukkan bahwa nilai mata pelajaran matematika, khususnya berkaitan dengan materi sifat-sifat bangun datar dari hasil ulangan formatif, siswa kelas V pada tahun pelajaran 2014/2015 dan tahun 20115/2016 masih rendah. Rendahnya hasil belajar siswa tersebut nampak berdasarkan hasil ulangan harian sebelumnya, dengan rata-rata diperoleh baru hanya $56,37 \%$ atau belum mencapai Kriteria Ketuntasan Minimal (KKM) yang ditetapkan oleh sekolah yakni 60\% dengan perolehan nilai di bawah 60 (data guru kelas V SD Negeri 1 Katoi Kabupaten Kolaka Utara). Sehingga ini masih jauh dari yang diharapkan.

Fenomena rendahnya nilai formatif Tahun Pelajaran 2014/2015 dan tahun 20115/2016 tersebut diduga karena siswa kurang memahami materi pelajaran yang disajikan oleh guru. Guru lebih cenderung menggunakan metode yang ceramah tanya jawab tanpa menggunakan alat peraga pada saat mengajar.Oleh karena itu, dituntut lebih kreatif dan inovatif memilih dan menerapkan suatu metode pembelajaran yang efektif. Jika sang guru lebih memperhatikan karakter anak usia SD, dengan harapan guru akan mengembangkan proses dan model pembelajaran aktif yang disesuaikan dengan karakter anak usia SD, tidak menutup kemungkinan akan diperoleh hasil belajar yang maksimal (Kaltsum, 2017, p.20).

Salah satu cara atau pendekatan yang dapat digunakan untuk mengatasi masalah tersebut adalah dengan menggunakan alat peraga dua dimensi sederhana. Gagne dan Briggs dalam Hidayat (2015, p.287) mengatakan bahwa media pembelajaran meliputi alat yang secara fisik digunakan untuk menyampaikan isi pembelajaran. Menurut Hamalik (2003) bahwa alat, metode, dan teknik dapat mengefektifkan komunikasi dan interaksi antara guru dan siswa dalam proses belajar mengajar. Dari pernyataan tersebut media dapat berbentuk alat, metode ataupun teknik mengajar yang dapat membawa suatu pesan pembelajaran. Dengan kata lain media adalah komponen dari sumber belajar peserta didik yang dapat menstimulasi peserta didik untuk belajar. Penggunaan alat peraga dua dimensi dalam pembelajaran matematika diduga akan mendorong siswa untuk aktif dalam mengikuti pembelajaran materi-materi yang diajarkan oleh guru, dan dapat menumbuhkan kreativitaskreativitas yang ada pada diri siswa.Dengan demikian, penggunaan alat peraga dua 
dimensidiharapkan dapat membantu siswa dalam memahami pembelajaran matematika. Menurut Putri (2017, p.6). Model pembelajaran kooperatif dengan memanfaatkan alat peraga sederhana dapat dijadikan sebagai alternative bagi guru dalam memilih strategi pengajaran yang bervariasi sehingga dapat memberikan pelayanan yang lebih baik kepada siswa dalam proses pembelajaran (Prasetyo \& Endah, 2014, p.4-5). Senada dengan Murdiyanto \& Yudi (2014, p.38) penggunaaan media maupun alat peraga secara kreatif akan memungkinkan siswa untuk belajar lebih baik dan dapat meningkatkan performan mereka sesuai dengan tujuan yang ingin dicapai.

Dengan bantuan alat peraga, guru dapat memberikan persepsi yang sama terhadap sesuatu benda atau peristiwa tertebntu kepada peserta didik. Kemudian persepsi yang sama akan menimbulkan pengertian dan pengalaman yang sama.

Mengingat permasalahan diatas mendorong penulis untuk mengambil fokus penelitian dengan judul "Upaya Meningkatkan Hasil Belajar Matematika Siswa pada Materi Sifat-sifat Bangun Datar dengan Menggunakan Alat peraga dua dimensidi Kelas V SD Negeri 1 Katoi Kabupaten Kolaka Utara”.

Masalah dalam penelitian ini adalah: 1) Apakah hasil belajar matematika pada materi sifat-sifat bangun datar dapat ditingkatkan dengan menggunakan alat peraga dua dimensi di kelas V SD Negeri 1 Katoi Kabupaten Kolaka Utara? 2) Apakah dengan menggunakan alat peraga dua dimensi pada materi sifat-sifat bangun datar dapat meningkatkan aktivitas guru di kelas V SD Negeri 1 Katoi Kabupaten Kolaka Utara 3) Apakah dengan menggunakan alat peraga dua dimensi pada materi sifat-sifat bangun datar dapat meningkatkan aktivitas belajaar siswa di kelas V SD Negeri 1 Katoi Kabupaten Kolaka Utara” Tujuan penelitian ini adalah 1) Untuk meningkatkan hasil belajar matematika pada materi sifat-sifat bangun datar melalui penggunaan alat peraga dua dimensi di kelas V SD Negeri 1 Katoi Kabupaten Kolaka Utara? 2) Untuk meningkatkan aktivitas guru melalui penggunaan alat peraga dua dimensi pada materi sifat-sifat bangun datardi kelas V SD Negeri 1 Katoi Kabupaten Kolaka Utara 3). Untuk meningkatkan aktivitas belajar siswa melalui penggunaan alat peraga dua dimensi pada materi sifat-sifat bangun datar di kelas V SD Negeri 1 Katoi Kabupaten Muna. Penelitian ini diharapkan dapat memberikan manfaat bagi guru, siswa, sekolah dan penelitian lainnya.

\section{Metode}

Jenis penelitian adalah penelitian tindakan kelas (PTK. Penelitian ini dilaksanakan di kelas V SD Negeri 1 Katoi Kabupaten Kolaka Utara dengan Subyek dalam penelitian ini adalah iswa kelas IV SD Negeri 1 Katoi pada semester ganjil tahun ajaran 2016/2017 berjumlah 15 orang. Penelitian tindakan kelas ini dilaksanakan dalam dua siklus yang terdiri dari empat tahapan yaitu perencanaan, pelaksanaan tindakan, observasi dan evaluasi serta refleksi Jenis data dalam penelitian ini adalah data kualitatif dan kuantitatif. Data kualitatif berupa kegiatan proses pembelajaran aktivitas belajar siswa dan aktivitas guru. Data kuantitatif berupa nilai hasil belajar siswa. Sumber data dalam penelitian ini adalah guru dan siswa Kelas V SD Negeri 1 Katoi Kabupaten Kolaka Utara.

Data kualitatif akan dianalisis secara deskriptif kualitatif berdasarkan observasi, sedangkan data kuantitatif dianalisis secara kuantitatif menggunakan rumus:

1. Menentukan persentase ketuntasan:

$$
\% \text { tuntas }=\frac{\sum f i}{n} \times 100 \%
$$

Dengan, $\quad \mathrm{n} \quad$ : Jumlah siswa secara keseluruhan

$\sum$ fi : Jumlah siswa pada kategori ketuntasan belajar

2. Menentukan Keberhasilan Aktivitas Mengajar Guru 


$$
\% \mathrm{KAMG}=\frac{\text { Jumlah Skor Perolehan Guru }}{\text { Jumlah Skor Maksimum }} \times 100 \%
$$

(Rohani, 2004, p.120)

3. Menentukan Keberhasilan Aktivitas Belajar Siswa

$$
\% \mathrm{KABS}=\frac{\text { Jumlah Skor Perolehan Siswa }}{\text { Jumlah Skor Maksimum }} \times 100 \%
$$

(Rohani, 2004, p.122)

Indikator keberhasilan dalam penelitian ini yaitu apabila terjadi perubahan pada sikap atau pemahaman siswa terhadap bahan ajar dalam proses pembelajaran. Yang berkaitan dengan pemahaman siswa apabila terjadi peningkatan skor rata-rata hasil belajar matematika siswa. Dikatakan tuntas secara klasikal minimal $80 \%$ yang nilainya $\geq 60$ dari skor ideal berdasarkan nilai KKM materi sifat-sifat bangun datar (ketentuan dari SD Negeri 1 Katoi Kabupaten Kolaka Utara).

\section{Hasil}

\section{Hasil Belajar Siswa}

Pada pembelajaran siklus I, 11 siswa memperoleh nilai $\geq 60$ dan 4 siswa memperoleh nilai <60. Evaluasi pada siklus I menunjukkan bahwa ketuntasan belajar siswa belum mencapai 80\%. Karena tingkat ketuntasan belajar siswa belum mencapai indikator keberhasilan maka penelitian dilanjutkan pada siklus II. pembelajaran siklus II, 14 siswa memperoleh nilai $\geq 60$ dan 1 siswa memperoleh nilai <60. Evaluasi pada siklus II menunjukkan bahwa ketuntasan belajar siswa telah mencapai $80 \%$. Dari hasil tes siklus II menunjukkan adanya peningkatan dan telah mencapai indikator keberhasilan yang telah ditetapkan, maka pelaksanaan tindakan dihentikan hanya sampai pada siklus II.

\section{Aktivitas Guru}

Hasil observasi terhadap guru pada proses pembelajaran siklus I menunjukkan bahwa skor perolehan guru pertemuan pertama adalah 9 dan pertemuan kedua adalah 12, maka persentase keberhasilan aktivitas mengajar guru siklus I pertemuan pertama adalah $69,2 \%$ dan pertemuan kedua adalah 92,3\%. Hasil observasi terhadap guru pada proses pembelajaran siklus II menunjukkan bahwa skor perolehan guru pada pertemuan pertama adalah 12 dan pertemuan kedua adalah 13, maka persentase keberhasilan aktivitas mengajar guru siklus II pertemuan pertama 93,3\% dan pertemuan kedua adalah $100 \%$.

\section{Aktivitas Siswa}

Hasil observasi terhadap siswa menunjukkan bahwa skor perolehan siswa pada siklus I pertemuan pertama adalah 7 dan pertemuan kedua adalah 10, maka persentase keberhasilan aktivitas belajar siswa siklus I pertemuan pertama adalah 53,8\% dan pertemuan kedua adalah 76,9\%. Dengan penjelasan yang baik dari guru, siswa dapat menjawab pertanyaan yang diberikan guru. Hasil observasi terhadap siswa menunjukkan bahwa skor perolehan siswa siklus II pertemuan pertama adalah 10 dan pertemuan kedua adalah 11. Sehingga persentase keberhasilan aktivitas belajar siswa siklus II pertemuan pertama adalah $84,6 \%$ dan pertemuan kedua adalah $100 \%$.

\section{Pembahasan}

Hasil belajar siswa pada Materi Sifat-sifat Bangun Datar yang ditunjukkan dengan nilai atau angka yang diperoleh melalui evaluasi pada setiap akhir siklus tindakan yang dilakukan guru. Pada pembelajaran siklus I, rata-rata nilai siswa adalah 72,2, jumlah siswa yang mencapai ketuntasan belajar adalah 11 orang $(73,3 \%)$ dan siswa yang belum mencapai ketuntasan belajar adalah 4 orang $(26,7 \%)$. Pada evaluasi pembelajaran siklus II nilai siswa menunjukkan peningkatan, dimana rata-rata nilai siswa adalah 88,8 dan jumlah siswa yang mencapai ketuntasan belajar adalah 14 orang $(93,3 \%)$ dan sisanya 1 orang $(6,7 \%)$ belum mencapai ketuntasan belajar. Hasil tersebut menunjukkan bahwa ketuntasan belajar siswa 
telah mencapai indikator yang telah ditetapkan. Hasil belajar yang diperoleh siswa pada penelitian ini sudah lebih baik jika dibandingkan dengan hasil belajar siswa pada tahun sebelumnya. Pada tahun ajaran 2012/2013, ketuntasan belajar siswa pada materi sifat-sifat bangun datar adalah $60 \%$ meningkat menjadi $93,3 \%$ setelah diadakan perbaikan pembelajaran melalui penelitian ini. Menurut Ulfah, dkk. (2016, p.1610) mengemukakan bahwa hasil belajar merupakan hasil keberhasilan dari interaksi belajar mengajar yang mencakup bidang kognitif, afektif, dan psikomotorik yang ditunjukkan dengan perubahan tingkah laku yang khas.

Hasil observasi aktivitas mengajar guru siklus I menunjukkan bahwa proses pembelajaran sudah berjalan dengan baik namun ada beberapa kekurangan yang dilakukan guru dan masalah yang dihadapi siswa. Kekurangan yang dilakukan guru dalam proses pembelajaran adalah guru tidak maksimal menggunakan alat peraga dua dimensi dalam pembelajaran. Guru lebih banyak menggunakan metode ceramah dalam menjelaskan materi pelajaran. Melihat kekurangan yang masih ada pada tindakan siklus I, maka penelitian dilanjutkan pada siklus II. Guru berusaha mendorong siswa untuk mampu mengungkapkan hasil pengamatannya dalam bentuk tulisan dan aktif dalam proses pembelajaran.

Hasil observasi terhadap guru pada proses pembelajaran siklus I menunjukkan bahwa skor perolehan guru pertemuan pertama adalah 9 dan pertemuan kedua adalah 12, maka persentase keberhasilan aktivitas mengajar guru siklus I pertemuan pertama adalah $69,2 \%$ dan pertemuan kedua adalah 92,3\%. Hal ini menunjukkan bahwa proses pembelajaran sudah berjalan dengan baik namun ada beberapa kekurangan yang dilakukan guru dan masalah yang dihadapi siswa dalam proses pembelajaran. Kekurangan yang dilakukan guru dalam proses pembelajaran adalah guru tidak maksimal menggunakan alat peraga dua dimensi dalam pembelajaran. Guru lebih banyak menggunakan metode ceramah dalam menjelaskan materi pelajaran.

Hasil observasi terhadap guru pada proses pembelajaran siklus II menunjukkan bahwa skor perolehan guru pada pertemuan pertama adalah 12 dan pertemuan kedua adalah 13, maka persentase keberhasilan aktivitas mengajar guru siklus II pertemuan pertama 93,3\% dan pertemuan kedua adalah $100 \%$. Hal ini menggambarkan bahwa proses pembelajaran siklus II sudah berjalan dengan baik, kekurangan yang dilakukan guru pada proses pembelajaran siklus I sudah teratasi. Guru menggunakan alat peraga dua dimensi dengan baik sehingga siswa aktif dalam proses pembelajaran.

Selama proses pembelajaran, observer mengamati aktivitas belajar siswa. Hasil observerasi siklus I menunjukkan bahwa masalah yang dialami siswa dalam proses pembelajaran adalah siswa belum mampu membahasakan hasil pengamatannya pada gambar dan belum mampu mmebuat kesimpulan dari kegiaatan pembelajaran. Walaupun demikian, siswa sudah berani membacakan hasil kerja kelompok di depan kelas meskipun susunannya belum baik.

Hasil observasi terhadap siswa menunjukkan bahwa skor perolehan siswa pada siklus I pertemuan pertama adalah 7 dan pertemuan kedua adalah 10, maka persentase keberhasilan aktivitas belajar siswa siklus I pertemuan pertama adalah 53,8\% dan pertemuan kedua adalah $76,9 \%$. Masalah yang dialami siswa dalam proses pembelajaran adalah siswa belum mampu membahasakan hasil pengamatannya pada gambar dalam bentuk tulisan dengan baik dan belum mampu mebuat kesimpulan dalam kegiatan pembelajaran. Walaupun demikian, siswa berani membacakan hasil diskusinya di depan kelas.

Pada pembelajaran siklus II, siswa sudah mampu membuat kesimpulan. Hasil observasi terhadap siswa menunjukkan bahwa skor perolehan siswa siklus II pertemuan pertama adalah 11 dan pertemuan kedua adalah 13. Sehingga persentase keberhasilan aktivitas belajar siswa siklus II pertemuan pertama adalah 84,6\% dan pertemuan kedua adalah 
$100 \%$. Pengorganisasian proses belajar mengajar dikelas dengan strategi pembelajaran yang tepat adalah salah satu hal yang harus benar-benar dipahami oleh guru selaku pendidik untuk meningkatkan aktivitas sekaligus hasil belajar siswa (Untari, 2013).

\section{Simpulan}

Berdasarkan hasil penelitian dan pembahasan, disimpulkan bahwa (1) Penggunaan alat peraga dua dimensi dapat meningkatkan aktivitas mengajar guru, (2) Dapat meningkatkan aktivitas belajar siswa, (3) Dapat memudahkan pencapaian ketuntasan belajar pada Materi Sifat-sifat Bangun Datar kelas V SD Negeri 1 Katoi Kabupaten Kolaka Utara

Peningkatan aktivitas mengajar guru ditunjukkan oleh kemampuan guru mengelola proses pembelajaran dengan baik. Persentase keberhasilan aktivitas mengajar guru siklus I pertemuan pertama adalah $69,2 \%$ dan pertemuan kedua adalah 92,3\%. Persentase keberhasilan aktivitas mengajar guru siklus II pertemuan pertama 93,3\% dan pertemuan kedua adalah $100 \%$.

Peningkatan aktivitas belajar siswa ditunjukkan oleh peningkatan keaktifan siswa dalam proses pembelajaran. Persentase keberhasilan aktivitas belajar siswa siklus I pertemuan pertama adalah $53,8 \%$ dan pertemuan kedua adalah 76,9\%. Persentase keberhasilan aktivitas belajar siswa siklus II pertemuan pertama adalah 84,6\% dan pertemuan kedua adalah $100 \%$.

Peningkatan Hasil Belajar Matematika Siswa pada Materi Sifat-sifat Bangun Datar dapat dilihat dari peningkatan rata-rata nilai dan ketuntasan belajar siswa. Rata-rata nilai siswa pada siklus I adalah 69,14 meningkat menjadi 76,03 pada siklus II. Jumlah siswa yang mencapai ketuntasan belajar pada siklus I adalah 16 orang $(55,17 \%)$ meningkat menjadi 27 orang $(93,10 \%)$ pada siklus II. Siswa yang belum mencapai ketuntasan belajar pada siklus I adalah 13 orang $(44,83 \%)$ menurun menjadi 2 orang $(6,90 \%)$ pada siklus II.

\section{Referensi}

Hamalik, O. (2003). Proses Belajar Mengajar. Jakarta: Bumi Aksara.

Hidayat, Panji. (2015). Alat Peraga Edukasi dan Moving Class dalam Pembelajaran di SD/MI. Universitas Ahmad Dahlan. http://www.academia.edu/download/56623555/2979-7727-1-PB.pdf

Hudoyo. Dkk. (2000). Pengembangan Kurikulum Matematika dan Pelaksanaannya di Depan Kelas.

Kaltsum, Honest Ummi. (2017). Pemanfaatan Alat Peraga Edukatif Sebagai Media Pembelajaran Bahasa Inggris Sekolah Dasar. Proceeding The 6th University Research Colloquium 2017. 19-24. Universitas Muhammadiyah Magelang. http://journal.ummgl.ac.id/index.php/urecol/article/view/1155

Murdiyanto, Tri \& Yudi Mahatma. (2014). Pengembangan Alat Peraga Matematika Untuk Meningkatkan Minat Dan Motivasi Belajar Matematika Siswa Sekolah Dasar. Jurnal $\begin{array}{lllll}\text { Sarwahita } & \text { Volume } & 11 & \text { No. } & 1 .\end{array}$ http://journal.unj.ac.id/unj/index.php/sarwahita/article/download/3318/2372/ 
Putri, Ariska Destia. (2017). Peningkatan Hasil Belajar Matematika Dengan Menggunakan Alat Peraga Jam Sudut Pada Peserta Didik Kelas IV SDN 2 Sunur Sumatera Selatan. Skripsi. Fakultas Tarbiyah dan Keguruan. Institut Agama Islam Negeri Raden Intan http://repository.radenintan.ac.id/461/1/Ariska_Destia_Putri.pdf

Lampung.

Rohani, Ahmad. (2004). Pengelolaan Pengajaran. Jakarta: PT. Rineka Cipta.

Sigit Ady Prasetyo, Endah Sudarmilah. (2014). Augmented Reality Tata Surya Sebagai Sarana Pembelajaran Interaktif Bagi Siswa Sekolah Dasar Berbasis Android. Skripsi. Teknik Informatika, Fakultas Komunikasi dan Informatika Universitas Muhammadiyah http://eprints.ums.ac.id/31314/14/NASKAH_PUBLIKASI.pdf

Surakarta.

Suparno. (2008). Ketrampilan Dasar Menulis. Jakarta: Universitas Terbuka,

Ulfah, K.R., Anang Santoso, Utaya, Sugeng. (2016). Hubungan Motivasi Dengan Hasil Belajar IPS. Jurnal Pendidikan: Teori, Penelitian, dan Pengembangan Volume: 1 Nomor: 8 Bulan Agustus Tahun 2016 Halaman: 1607-1611 http://journal.um.ac.id/index.php/jptpp/article/view/6678/2885

Untari, Yusrina Anggraini. (2013). Peningkatan Hasil Belajar IPS Siswa Kelas V Melalui Metode Simulasi Improved Results of IPS Learning Student Class V through Simulation Method. Psikopedagogia Jumal Bimbingan dan Konseling. Vol. 2, No. 2. 78-84.

http://journal.uad.ac.id/index.php/PSIKOPEDAGOGIA/article/view/2574/2792 